\title{
Contents of Volume 119 (2015)
}

Allison, P.M., Characterizing Roman Artifacts for Investigating Gendered Practices in Contexts Without

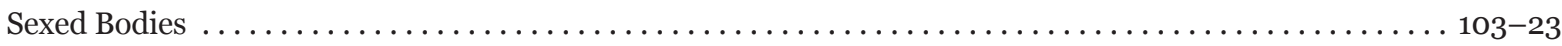

Andrews, M.M., and H.I. Flower, Mercury on the Esquiline: A Reconsideration of a Local Shrine Restored

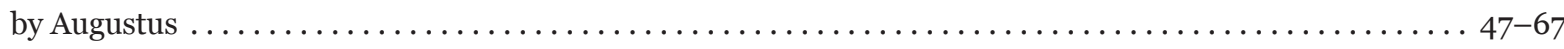

Archaeological Institute of America, Awards Presented at the 116th Annual Meeting of the Archaeological

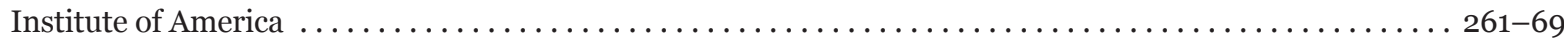

Attanasio. See Bruno et al.

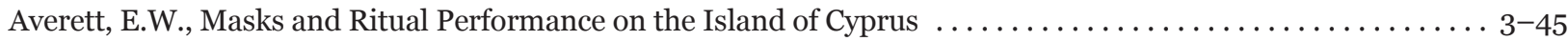
Berthon. See Laneri et al.

Bruno, M., D. Attanasio, and W. Prochaska, The Docimium Marble Sculptures of the Grotto of Tiberius at

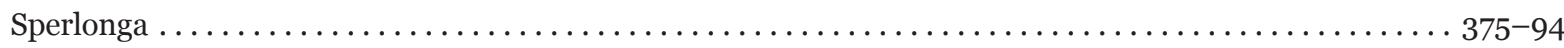

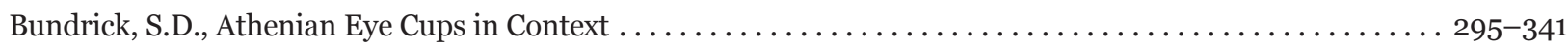

Camp. See Rousset et al.

Cova, E., Stasis and Change in Roman Domestic Space: The Alae of Pompeii's Regio VI .............69-102 D'Agostino. See Laneri et al.

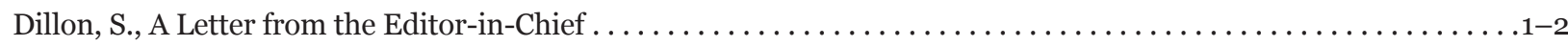

Flower. See Andrews and Flower.

Frey, J.M., The Archaic Colonnade at Ancient Corinth: A Case of Early Roman Spolia . . . . . . . . . . . . . 147-75

Gerrard, J.F., Synthesis, Chronology, and "Late Roman" Cemeteries in Britain . . . . . . . . . . . . . 565-72 Guliyev. See Nishiaki et al.

Hald. See Laneri et al.

Harris, W.V., Prolegomena to a Study of the Economics of Roman Art . . . . . . . . . . . . . 395-417

Hollinshead, M.B., The North Court of the Erechtheion and the Ritual of the Plynteria ............. 177-90

Kadowaki. See Nishiaki et al.

Keenan-Jones, D., Somma-Vesuvian Ground Movements and the Water Supply of Pompeii and the Bay

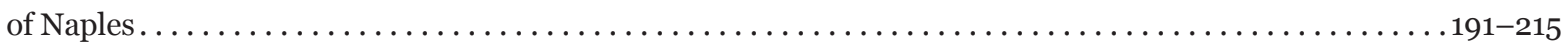

Laneri, N., M. Schwartz, J. Ur, A. D’Agostino, R. Berthon, M.M. Hald, and A. Marsh, Ritual and Identity in Rural Mesopotamia: Hirbemerdon Tepe and the Upper Tigris River Valley in the Middle

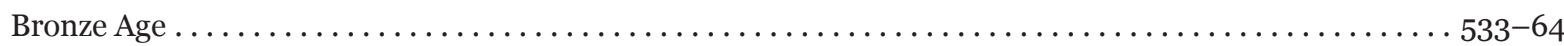

Lichtenberger, A., and R. Raja, New Archaeological Research in the Northwest Quarter of Jerash and Its Implications for the Urban Development of Roman Gerasa $\ldots \ldots \ldots \ldots \ldots \ldots \ldots \ldots \ldots \ldots \ldots$

Marsh. See Laneri et al.

McKenzie-Clark, J., Distinguishing Between Rouletting and Chattering on Ancient Mediterranean Pottery ... . 137-43 Minon. See Rousset et al.

Nishiaki, Y., F. Guliyev, and S. Kadowaki, Chronological Contexts of the Earliest Pottery Neolithic in the South Caucasus: Radiocarbon Dates for Göytepe and Hacı Elamxanlı Tepe, Azerbaijan . . . . . . . . . . . 279-94

Nishimura, Y., A Systematic Comparison of Material Culture Between Household Floors and Residential Burials in Late Third-Millennium B.C.E. Mesopotamia $419-40$ 
Pedersen, R.K., A Preliminary Report on a Coastal and Underwater Survey in the Area of Jeddah,

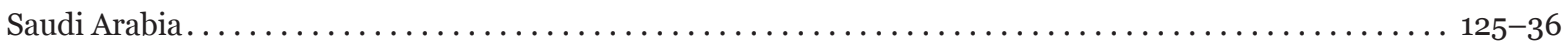

Popkin, M.L., Samothracian Influences at Rome: Cultic and Architectural Exchange in the Second

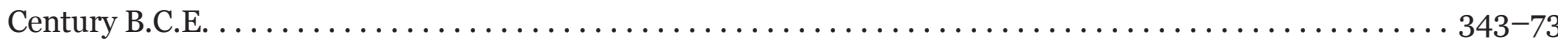

Prochaska. See Bruno et al.

Raja. See Lichtenberger and Raja.

Rousset, D., J. Camp, and S. Minon, The Phokian City of Panopeus/Phanoteus, Three New Rupestral

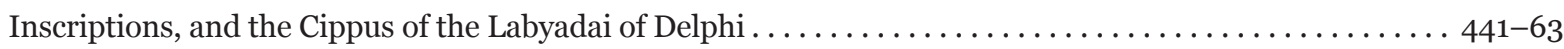

Rowan, E., Olive Oil Pressing Waste as a Fuel Source in Antiquity . . . . . . . . . . . . . . . . 465-82 Schwartz. See Laneri et al.

Sturgeon, M.C., Five Recent Books on Hellenistic and Roman Sculptures from the Greek East and Italy. . . . . . 271-77 Sweetman, R.J., Memory, Tradition, and Christianization of the Peloponnese . . . . . . . . . . . . . 501-31 Swetnam-Burland, M., Encountering Ovid's Phaedra in House V.2.10-11, Pompeii . . . . . . . . . . . . . 217-32 Wood, S., Women in Action: A Statue of Matidia Minor and Its Contexts $\ldots \ldots \ldots \ldots \ldots \ldots \ldots$ Ur. See Laneri et al.

\section{ONLINE ONLY (open access at www.ajaonline.org)}

\section{Supplementary Content}

Bruno, M., D. Attanasio, and W. Prochaska, Appendix: Analytical Data for 47 Samples from the Quarries of Lithos Lartios at Rhodes

Cova, E., Image Gallery: Stasis and Change in Roman Domestic Space: The Alae of Pompeii's Regio VI

Frey, J.M., Image Gallery: The Archaic Colonnade at Ancient Corinth: A Case of Early Roman Spolia

Nishiaki, Y., F. Guliyev, and S. Kadowaki, Appendix: Results of a Bayesian Analysis of Radiocarbon Dates from Göytepe and Hacı Elamxanlı Tepe, Azerbaijan

Sweetman, R.J., Image Gallery: Memory, Tradition, and Christianization of the Peloponnese

Necrology

Sturgeon, M.C., Georgos I. Despinis, 1936-2014

\section{Review Article}

Johnson, J.A., Out of Order, Out of Time: Interrogating Current Approaches to European Prehistory

\section{Book Reviews}

Barker, S.J., Rev. of Boin, Ostia in Late Antiquity

Beaulieu, M.-C., Rev. of Pevnick, ed., Poseidon and the Sea: Myth, Cult, and Daily Life

Borbonus, D., Rev. of Joshel and Petersen, The Material Life of Roman Slaves

Bultrighini, I., Rev. of Camia, Theoi Sebastoi: Il culto degli imperatori romani in Grecia (provincia Achaia) nel secondo secolo D.C.

- Rev. of Stroud, The Sanctuary of Demeter and Kore: The Inscriptions

Burton, D., Rev. of Grossman, Funerary Sculpture

Published online October 2015 American Journal of Archaeology 119.4 
Chavela, K., Rev. of Tarlow and Nilsson Stutz, The Oxford Handbook of the Archaeology of Death and Burial

Conant, J.P., Rev. of Leone, The End of the Pagan City: Religion, Economy, and Urbanism in Late Antique North Africa

Curtis, R.I., Rev. of Marzano, Harvesting the Sea: The Exploitation of Marine Resources in the Roman Mediterranean

DeLaine, J., Rev. of Ulrich and Quenemoen, eds., A Companion to Roman Architecture

Devolder, M., Rev. of Broodbank, The Making of the Middle Sea: A History of the Mediterranean from the Beginning to the Emergence of the Classical World

Doonan, O., Rev. of Ivanova, The Black Sea and the Early Civilizations of Europe, the Near East, and Asia

Downing, C., Rev. of Barbet, Peintures romaines de Tunisie

—_ Rev. of Boislève, Dardenay, and Monier, eds., Peintures murales et stucs d'époque romaine: De la fouille au musée

Draycott, C.M., Rev. of Karagöz, Kleinasiatisch-Gräko-Persische Kunstwerke im Archäologischen Museum von Istanbul

Dyson, S.L., Rev. of Keay, ed., Rome, Portus and the Mediterranean

Emerson, T.E., Rev. of Birch, ed., From Prehistoric Villages to Cities: Settlement Aggregation and Community Transformation

— Rev. of Creekmore III and Fisher, eds., Making Ancient Cities: Space and Place in Early Urban Societies

Fentress, E., Rev. of Medri and di Cola, Ostia V: Le terme del nuotatore. Cronologia di un'insula ostiense

Filis, K., Rev. of Lawall and Lund, eds., The Transport Amphorae and Trade of Cyprus

Francis, J.E., Rev. of Coutsinas, Défenses crétoises: Fortifications urbaines et défense du territoire en Crète aux époques classique et hellénistique

Gaignerot-Driessen, F., Rev. of Day and Glowacki, Kavousi IIB: The Late Minoan IIIC Settlement at Vronda. The Buildings on the Periphery

Gaunt, J., Rev. of Eschbach, Corpus vasorum antiquorum. Germany 92. Archäologisches Institut der Universität Göttingen 4: Attisch Rotfigurige Keramik

Gauss, W., Rev. of Mühlenbruch and Damm-Meinhardt, Baubefunde und Stratigraphie der Unterburg und des nordwestlichen Stadtgebiets (Kampagnen 1976 bis 1983). Pts. 2, 3

Graf, D.F., Rev. of MacDonald, Herr, Quaintance, Clark, and Macdonald, The Ayl to Ras an-Naqab Archaeological Survey, Southern Jordan 2005-2007

Graninger, D., Rev. of Funke and Haake, eds., Greek Federal States and Their Sanctuaries: Identity and Integration

Hadji, A., Rev. of Robb and Harris, eds., The Body in History: Europe from the Palaeolithic to the Future

Herscher, E., Rev. of Webb and Frankel, Ambelikou Aletri: Metallurgy and Pottery Production in Middle Bronze Age Cyprus

Hogue, S.L., Rev. of Hope Simpson, Mycenaean Messenia and the Kingdom of Pylos

Hurwit, J.M., Rev. of Eaverly, Tan Men/Pale Women: Color and Gender in Archaic Greece and Egypt. A Comparative Approach

Jennings, J., Rev. of Knappett, ed., Network Analysis in Archaeology: New Approaches to Regional Interaction

Kierstead, J., Rev. of Kellogg, Marathon Fighters and Men of Maple: Ancient Acharnai

Kleiner, F.S., Rev. of Guidobaldi and Esposito, Herculaneum: Art of a Buried City

Koloski-Ostrow, A.O., Rev. of Rogers, Water and Roman Urbanism: Towns, Waterscapes, Land Transformation and Experience in Roman Britain

Kotsonas, A., Rev. of Kerschner and Lemos, eds., Archaeometric Analyses of Euboean and Euboean Related Pottery: New Results and Their Interpretations. Proceedings of the Round Table Conference Held at the Austrian Archaeological Institute in Athens, 15 and 16 April 2011 
Kouremenos, A., Rev. of Platts, Pearce, Barron, Lundock, and Yoo, eds., TRAC 2013: Proceedings of the Twenty-Third Theoretical Roman Archaeology Conference, King's College, London, 4-6 April 2013

Landskron, A., Rev. of Birk, Kristensen, and Poulsen, eds., Using Images in Late Antiquity

— Rev. of Strocka, Hoffmann, and Heisel, Die Bibliothek von Nysa am Mäander

Langridge-Noti, E., Rev. of Carpenter, Lynch, and Robinson, eds., The Italic People of Ancient Apulia: New Evidence from Pottery for Workshops, Markets, and Customs

Lawall, M.K., Rev. of Tsingarida and Viviers, eds., Pottery Markets in the Ancient Greek World (8th-1st Centuries B.C.): Proceedings of the International Symposium Held at the Université libre de Bruxelles 19-21 June 2008 Leach, E.W., Rev. of Barbet and Verbanck-Piérard, eds., La villa romaine de Boscoreale et ses fresques. 2 vols. Letesson, Rev. of Souvatzi and Hadji, eds., Space and Time in Mediterranean Prehistory

Madigan, B., Rev. of Kristensen, Making and Breaking the Gods: Christian Responses to Pagan Sculpture in Late Antiquity

Maeir, A.M., Rev. of Porter, Complex Communities: The Archaeology of Early Iron Age West-Central Jordan

Mannack, T., Rev. of Schöne-Denkinger, Corpus vasorum antiquorum. Germany 95. Berlin 15: Attisch rotfigurige und schwarzgefirnisste Peliken, Loutrophoren und Lebetes Gamikoi

McConnell, B.E., Rev. of Bergemann, ed., Der Gela-Survey: 3ooo Jahre Siedlungsgeschichte in Sizilien. 3 vols.

Meyers, G.E., Rev. of De Puma, Etruscan Art in the Metropolitan Museum of Art

Moore, M.B., Rev. of Papuci-Władyka, Corpus vasorum antiquorum. Poland 11. Krakow 1: Jagiellonian University Institute of Archaeology 1 and Jagiellonian University Museum

Neils, J., Rev. of Zimmerman-Elseify, Corpus vasorum antiquorum. Germany 93. Berlin 13: Attisch rotfigurige Lekythen

Papalexandrou, N., Rev. of Smith and Plantzo, eds., A Companion to Greek Art

Pavel, C., Rev. of Bonde and Houston, eds., Re-Presenting the Past: Archaeology Through Text and Image

Petrakis, V., Rev. of Whittaker, Religion and Society in Middle Bronze Age Greece

Poehler, E., Rev. of Crouwel, Chariots and Other Wheeled Vehicles in Italy Before the Roman Empire

Raja, R., Rev. of Smith, Roman Palmyra: Identity, Community, and State Formation

Richards, J.D., Rev. of Shugar and Mass, eds., Handheld XRF for Art and Archaeology

Rojas, F., Rev. of Hamilakis, Archaeology and the Senses: Human Experience, Memory, and Affect

Russell, N., Rev. of Ekroth and Wallensten, eds., Bones, Behaviour and Belief: The Zooarchaeological Evidence as a Source for Ritual Practice in Ancient Greece and Beyond

Sewell, J., Rev. of Evans, ed., A Companion to the Archaeology of the Roman Republic

Stannish, S.M., Rev. of Wilburn, Materia Magica: The Archaeology of Magic in Roman Egypt, Cyprus, and Spain

Steele, P.M., Rev. of Michaelides, ed., Epigraphy, Numismatics, Prosopography and History of Ancient Cyprus: Papers in Honour of Ino Nicolaou

Stronk, J.P., Rev. of Hall, Artifact and Artifice: Classical Archaeology and the Ancient Historian

Taylor, R., Rev. of Richard, Water for the City, Fountains for the People: Monumental Fountains in the Roman East

Uhlenbrock, J., Rev. of Bencze, Physionomie d'une cité grecque: Développements stylistiques de la coroplathie votive archaïque de Tarente

Walsh, J. St. P., Rev. of Papadopoulos and Urton, eds., The Construction of Value in the Ancient World

Woolf, G., Rev. of Wells, ed., Rome Beyond Its Frontiers: Imports, Attitudes and Practices

Younger, J.G., Rev. of Ferrara, Cypro-Minoan Inscriptions. Vol. 1, Analysis

- Rev. of Duhoux and Morpurgo Davies, eds., A Companion to Linear B: Mycenaean Greek Texts and Their World 